\title{
Bódi, F., Fábián, G., Fónai, M., Kurkinen, J., Lawson, T. R., Pietiläinen, H. (eds.): Access to services in rural areas: A comparison of Finland and Hungary (Europäischer Hochschulverlag, Bremen, 2014. 315 o.)
}

\author{
LENNERT JÓZSEF
}

\begin{abstract}
LENNERT József: tudományos segédmunkatárs, MTA Közgazdaság- és Regionális Tudományi Kutatóközpont, Regionális Kutatások Intézete; 6000 Kecskemét, Rákóczi út 3.; lennert@rkk.hu
\end{abstract}

József LENNERT: junior research fellow, Institute for Regional Studies, Centre for Economic and Regional Studies, Hungarian Academy of Sciences; Rákóczi út 3., H-6000 Kecskemét, Hungary; lennert@rkk.hu

A komplex területi kutatások között kiemelt figyelmet érdemelnek azok, amelyek két (vagy több) téregység párhuzamos feltárását és összehasonlító elemzését vállalják fel, elősegítve ezzel az eredmények tágabb keretbe helyezését, az általános térfolyamatok és az egyedi vonások elkülönítését.

Megvannak az előnyei annak is, ha szomszédos és hasonló környezeti-társadalmi-gazdasági adottságokkal rendelkező régiók összehasonlító elemzését végezzük el, és annak is, ha földrajzilag távol eső, számos szempontból eltérő mintaterületekre esik a választásunk. Utóbbi esetben, eltérő társadalmi-gazdasági környezetben különösen érdekes lehet egy-egy markáns hasonlóság megnyilvánulásának vizsgálata. Jelen könyv is erre tesz kísérletet Finnország és Magyarország két jelentős kiterjedésű vidéki és periferikus területeket tartalmazó régiójának (Észak-Pohjanmaa és Észak-Alföld) összehasonlításával. A szerkesztők közül 3 magyarországi (Bódi Ferenc, Fábián Gergely, Fónai Mihály), két finn (Jorma Kurkinen és Hannu Pietiläinen) valamint egy egyesült államokbeli (Thomas R. Lawson) és az ehhez hasonlóan több országból verbuválódó szerzőgárda garancia a téma - a helyi szolgáltatásokhoz való hozzáférés - sokoldalú feltárására. A kötetben egymást követik a finn, illetve magyar fókuszú fejezetek, amelyek öt nagyobb tematikus egységbe rendeződnek. Az elméleti bevezető és a módszertani keretek lefektetése után a magyarországi és finnországi helyi szociális ellátórendszerek bemutatása következik. Ezt követi a két mintarégió általánosabb földrajzi sajátosságait bemutató egység, végül a kötet a két mintarégió helyi szociális ellátórendszerének és a helyi lakosság alapvető szolgáltatásokhoz való hozzáférésének részletes bemutatásával zárul.

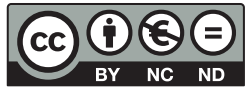


A helyi szociális ellátórendszerek elméleti bemutatására az első fejezet (Bódi F.) kerít sort. A helyi társadalom jóllétének biztosításához hozzájáruló ellátórendszerek három területre bonthatók: oktatás, egészségügy és szociális támogatások. A formális ellátásokat biztosíthatja a központi kormányzat, regionális/megyei/tartományi kormányzatok, a helyi önkormányzatok, az NGO-k/civil szervezetek és az egyházak is. De a helyi szociális ellátások jelentős része nem formalizált intézményi struktúrában történik, amelynek alapelemét az egyes családok adják, de részét képez(het)ik a szomszédsági, rokonsági, barátsági és munkahelyi kapcsolatok is. A helyi szociális ellátórendszerek vizsgálatát a - részben - törvényileg szabályozott kínálati oldalon kívül meg lehet közelíteni keresleti oldalról is, ami sok tényezőtől (társadalmi, gazdasági) függve minden közösségben egyedi lesz. Míg a korábbi modellek (pl. Trento-modell) a helyi szociális ellátórendszerek szilárd jóléti államban működő, szimmetrikus modelljét vázolták fel, a 2008-as jelzálogpiaci válság után előtérbe kerültek a dinamikus modellek, amelyeket a keresleti és kínálati oldal aszimmetriája jellemez. A szociális ellátórendszerek az aszimmetria feloldására, egyensúlyi állapotra törekszenek, és az átrendeződési folyamatok gyakran paradigmaváltásokhoz kapcsolódva ciklikus jelleget öltenek. Ezalól Magyarország sem kivétel, ahol 2010-től ismét napirendre került a helyi szociális ellátórendszerek gyökeres átszabása, Finnországban pedig 2005-től vette kezdetét a helyi önkormányzatok és szolgáltatások fokozatosan végrehajtott újraszervezése.

Magyarországon a decentralizációnak nincsenek erős történeti hagyományai (Csürös, Krizsai). A rendszerváltás után létrehozott helyi önkormányzati rendszer széles körű autonómiát biztosított, feladatkörei alapján leginkább a skandináv önkormányzati modellre, elaprózottsága alapján leginkább a mediterrán önkormányzati modellre hajazott. Ez a forráshiányban szenvedő hibrid modell számos tekintetben diszfunkcionális volt, és a rendszerváltás óta több reformkísérletnek is célpontja volt (pl. a finanszírozást és az egyes területi szintek feladatait érintve). A 2010 után elkezdődött reformfolyamat azonban a korábbiaktól eltérően alapjaiban kérdőjelezte meg a rendszerváltás óta kialakított decentralizációt, az erősebb állami szerepvállalásra és a centralizációra helyezve a hangsúlyt. A szemléletbeli váltáson túl a gyakorlatban ismételten a területi szintek átszabásában (járások), feladatkörük újradefiniálásában, valamint pénzügyi reformokban (feladatközpontú finanszírozás előtérbe helyezése) öltött testet. A fejezet írója, Csűrös Gabriella véleménye szerint azonban az átalakítások több szempontból is problematikusak, például a helyi önkormányzatok politikai és pénzügyi autonómiájának csökkentése ellentmond a Helyi önkormányzatok európai chartájában rögzített alapelveknek, valamint nem ért egyet az egyes feladatok kiszervezésének ellehetetlenítésével sem. A szerző meggyőződése, hogy bizonyos feladatok kiszervezése növelheti a hatékonyságot, és a korábbi negatív tapasztalatokért (pl. a PPP-beruházásokkal kapcsolatban) elsősorban a szabályozási környezet hiányosságai tehetők felelőssé. 
Finnország késői csatlakozóként a jóléti államok szociáldemokrata modelljét adaptálta, így a jólléti rendszerére jellemző a juttatások egységes, széles körű törvényi szabályozása, lakóhelyhez kötése és koordinálása, az egyén középpontba helyezése és a társadalmi segítségnyújtást igénylő helyzetek széles skálájának lefedése (Nyilas). Magyarországgal ellentétben Finnországban összhang van a szociális szolgáltatások modellje és az önkormányzati rendszer között: a kiterjedt és széles körű jóléti szolgáltatásokat kevés, viszonylag nagy népességü önkormányzat biztosítja (skandináv típusú önkormányzati rendszer). Ennek megfelelően a központi szakpolitikák támogatják a kisebb önkormányzatok összeolvadását, és Magyarországgal ellentétben az önkormányzatok száma csökken (1990: 460; 2013: 320) (Kilpeläinen). A finn és magyar szociális ellátórendszer között jelentős eltérés mutatkozik az NGO-k szerepe szempontjából is. Míg Magyarországon a civil szervezetek nem töltenek be jelentős szerepet a szociális ellátórendszerben, Finnországban komoly hagyománya van a nem kormányzati szervezetek feladatvállalásának. Szerepük különösen a kis falvakban és a félreeső vidéki területeken jelentős (Kilpeläinen).

A Botteni-öböltől az orosz határig terjedő, északról a Lappfölddel határos Észak-Pohjanmaa Finnország második legnagyobb NUTS 3-as régiója. 37000 $\mathrm{km}^{2}$-nyi területén 380000 ezer ember talál otthonra, ebből azonban 240000 ember a régióközpont, Oulu városrégiójában él. A népesség nagyobb részét tömörítő városi központ és a régió területének oroszlánrészét alkotó, ritkán lakott önkormányzatok között jelentős a kontraszt, ami kihívást jelent a szociális szolgáltatások szervezésében és a kérdőíves felmérés eredményeiben is megmutatkozik. Míg a gyarapodó népességű Oulu jelentős vándorlási célpont, addig a régió többi része elöregedéssel és elnéptelenedéssel néz szembe. Oulu és a félreeső vidékek közti különbségek a lakosság képzettségének az eltérésében is megnyilvánulnak. Finnország többi részéhez képest Észak-Pohjanmaaban magasabb a gyermekes családok aránya, és a finn átlaghoz képest magasabb a szegénységi küszöb alatt élő családok aránya. A munkanélküliségi statisztikák rosszabbak a finn átlagnál. Különösen igaz ez a fiatal álláskeresőkre: minden ötödik fiatal munkanélküli. Mind a munkanélküliség, mind a különböző szociális és lakástámogatások szempontjából nagyok a területi különbségek. A morbiditási index, a rokkantnyugdíjak magasabb száma és a hamarabb bekövetkező nyugdíjba vonulás mind a lakosság átlagosnál rosszabb egészségi állapotáról tanúskodik. Ez, a fokozatos elöregedéssel és elnéptelenedéssel társulva, komoly kihívást jelent a félreeső vidéki önkormányzatok számára. Az egészségügyi és jóléti szolgáltatások biztosítása és finanszírozása az önkormányzatokat terheli, és a kis népességü önkormányzatoknak egyre nehezebb előteremteni a szükséges forrásokat. Ez pedig gyakran kényszerű, rövidlátó döntésekhez vezet, mint pl. a preventív szociális ellátás visszafejlesztése (Kurkinen).

Magyarországról ehhez hasonlóan egy, az országosnál rosszabb társadalmi és gazdasági helyzettel rendelkező periferikus régióra, az Észak-Alföldre esett a 
választás. A rövid statisztikai helyzetértékelésben a munkanélküliségi ráta és a jövedelemszint a teljes régió elmaradásáról tanúskodik, míg a szociális segélyekben részesülők aránya a régión belüli kiugró különbségekre világít rá. A megyeszékhely excentrikus fekvésének is köszönhetően Szatmár és Bereg mind országos, mind regionális léptékben külső perifériának tekinthetők, ahol a szociális segélyben részesülők száma a települések többségében meghaladja az adófizetők 80\%-át (Bódi M.).

A régió országoshoz képesti társadalmi leszakadásának bemutatásához a szerzők a fenti statisztikai alapmutatókon túl a társadalmi anómia elméleti koncepcióját is segítségül hívják (Bódi, Farkas, Horváth). Durkheim anómiakoncepciója az 1929-es nagy gazdasági világválsággal kapcsolatban merült fel először. Célja, hogy az egyén (mentális) egészségi állapotát összekapcsolja a társadalmi dinamikával, példaként a társadalmi anómia egyik szélső megnyilvánulását, az öngyilkosságot elemezve. Merton, a koncepció továbbfejlesztője a társadalmi anómiának négy alaptípusát különíti el (innovatív, ritualizáló, visszavonuló, lázadó). A nagy gazdasági világválságot megelőző társadalmi hangulat (a lehetőségek és társadalmi realitások, valamint az egymásnak is ellentmondó értékrendszerek kontrasztja) megágyazott a válságot követően a társadalmi érvényesülés korábbi intézményesült kereteitől való elfordulásnak. A korábban kulturálisan beágyazódott célok eléréséhez innovatív, új utakat kereső, gengszter attitűd társul. A szerzők meglátása szerint ez a helyzet nagyban hasonlít a Kelet-Közép-Európában a rendszerváltás után végbement folyamatokra. De a többi anómia-alaptípus esetében is elmondható, hogy megvannak a térségbeli megfelelői. Az anómia egyik mérőszámaként a társadalmi kapacitás szolgál. Ahol alacsony a társadalmi kapacitás, ott számolni kell az anómia tüneteinek megjelenésével. Bódi Ferenc, Farkas Jenő és Horváth Zsuzsanna - egy korábbi, Juhász Attila és kollégái (Juhász et al. 2010) által kidolgozott deprivációs indexet alapul véve - a társadalmi kapacitás mérésére a jelenség sokdimenziósságának megfelelően komplex mutatót alakítottak ki, és végezték el a vizsgálatot Magyarország területére. A komplex mutató a következő mutatókból tevődött össze:

- A jogerősen elítélt bűnelkövetők aránya.

- A járadékosok aránya az adófizetőkhöz képest.

- Az egy adófizetőre jutó jövedelem.

- Az adófizetők aránya a 18-59 éves lakossághoz képest.

- A lakónépesség változása.

- A terhességmegszakítások száma a szülőképes korú nőkhöz viszonyítva.

- A korai halálozás kockázata.

A társadalmi kapacitás értékei is országunk jól ismert térszerkezeti vonásait rajzolják ki: a társadalmi kapacitás magas az ország északnyugati egyötödében és a nagyvárosi agglomerációkban, és alacsony a délnyugati és északkeleti külső perifériák településein. Ami a mintaterületet, az Észak-Alföld régiót illeti, a társadalmi kapacitás indexében is megmutatkozik a megyeszékhelyek és a 
félreeső kistelepülések társadalmi helyzete között tátongó szakadék: joggal feltételezhető, hogy ezeket a településeket a gazdasági nehézségek mellett - vagy éppen ezek miatt - társadalmi anómia jellemzi, konzerválva leszakadt, sodródó állapotukat.

A kötet empirikus részei Észak-Pohjanmaa és Észak-Alföld szociális ellátórendszerét fölmérő, egymással összevethető kérdőívezéseken alapulnak. A finnországi kérdőíves felméréseket a Poske - Northern Finland Centre of Excellence on Social Welfare készítette 2003 és 2011 között. A kérdőíves vizsgálatokból 6 lakossági felmérés volt, összesen mintegy 10000 fös mintával, 3 pedig a szociális ellátórendszer szolgáltatóit vonta be a vizsgálatba. Az adatgyüjtés módja változó volt, a kérdőívek egy részét interneten, de volt, amit postai úton vagy kérdezőbiztossal juttattak el a kérdezetthez (Kurkinen). A magyar féllel való együttműködés ötlete és a komparatív vizsgálat végrehajtása 2010-ben merült fel; ennek az együttműködésnek a gyümölcse ez a kötet. Épp ezért az észak-alföldi kérdőívezés kialakításakor fokozottan figyeltek arra, hogy az eredmények a finnországival összevethetők legyenek. A magyarországi kérdőíves adatfelvétel háztartások szerint történt, de a kérdőívezés alanyai a háztartásokban élő személyek voltak. A minta nagysága mintegy ezer fö volt, és a minta nemre, korra és településtípusra reprezentatívnak tekinthető. A lekérdezés személyesen történt, a kérdezőbiztosok tapasztalataikról terepnaplót vezettek (Fónai, Patyán).

A kérdések egy része a lakosság szubjektív jóllétére vonatkozott. ÉszakPohjanmaa esetében elmondható, hogy a lakosok nagy része általánosságban elégedett az életével (Kurkinen). Magyarországra ez sajnos nem áll meg, az Észak-Alföldön a kép inkább vegyesnek mondható (Fónai, Fábián). A jóllét különböző dimenzióinak szubjektív megítélése között mindkét régióban nagy eltérések vannak. Az Észak-Pohjanmaaban végzett kérdőívezések a lakhatással, lakókörnyezettel és biztonsággal, valamint a szellemi egészséggel és az emberi kapcsolatokkal való nagyfokú elégedettséget mutatták ki, azonban a gazdasági helyzetükre, foglalkoztatási helyzetükre, szolgáltatásokhoz való hozzáférésükre és különösen az oktatási, képzési lehetőségekhez való hozzáférésükre jóval gyakrabban adtak alacsonyabb értéket az ötfokozatú Likert-skálán ( 1 - rossz, 5 - jó). Ugyanezt az értékelést a szolgáltatásellátók is elvégezték. A kapott értékek a legtöbb dimenzióban nagyjából összhangban vannak a lakossági kérdőívezés eredményeivel, de például a régió lakóinak mentálhigiénés állapotát a kérdezetteknél szignifikánsan rosszabbnak értékelték (Kurkinen). Az Észak-Alföldön a kérdezettek kifejezetten rossznak értékelték a pénzügyi helyzetüket, emellett jelzésértékü, hogy - az emberi kapcsolataik mellett - az önellátásra való képességüket is jónak ítélték. Ez arra utalhat, hogy kevéssé számíthatnak az állami, önkormányzati szociális juttatásokra, emiatt válsághelyzetekben felértékelődnek az önerőből és a kapcsolati háló segítségével boldogulás fortélyai. A roma és nem roma lakosság szubjektív jóllétében számottevő különbségek mutatkoznak. A roma megkérdezettek a jóllét minden kialakított dimenziójában alacso- 
nyabb értékeket adtak, ám a legkirívóbb különbség a foglalkoztatási helyzetre rákérdezve jelentkezett. Egyes dimenziók megítélésében nagy differenciák vannak a kérdezettek lakóhelye szerint is, de míg például a szabadidős lehetőségek értékelése folyamatosan csökken a megyeszékhelyektől a városokon át a községekig, a foglalkoztatási lehetőségek esetében a megyeszékhelyen élők megítélése ugyan jobb, de a városok és községek kérdezettjeinek értékelése között már nincs különbség (Fónai, Fábián). A periferikus helyzet negatív hatása még a fejlett szociális ellátórendszerrel rendelkező Finnországban is megjelenik. Míg a szélesebb csoportoknak szóló ellátásokkal (bölcsőde, iskola, gyermekorvos) a kérdezettek elégedettek, a speciális egészségügyi szolgáltatásokkal, valamint a munkába állást segítő szolgáltatásokkal szemben már nagyobb elégedetlenség mutatkozik.

Érdekes azt is összehasonlítani, hogy a két régióban mekkora jelentőséget tulajdonítanak a szociális ellátórendszer intézményesült, illetve nem intézményesült szereplőinek. A szűkebb családi kör mindkét országban az élre került, azonban Észak-Pohjanmaa esetében a válaszok tanúsága szerint nagy jelentőséget tulajdonítanak az önkormányzati egészségügyi és társadalombiztosítási szolgáltatásoknak, míg Észak-Alföld esetében a tágabb rokonság és a barátok kerülnek előtérbe (Huszti). Ez ismét arra utal, hogy Finnországgal szemben Magyarországon nagyobb a jelentősége a szociális ellátórendszer formális struktúrákon kívüli, kapcsolati hálókon nyugvó részének.

A kötetről összességében elmondható, hogy a lehetőségekhez képest kevéssé aknázza ki a két régió összehasonlításában rejlő potenciált. Az egy-egy területegységre koncentráló fejezetek jórészt párhuzamba állíthatók, bár egy-egy téma kapcsán gyakran eltérő a szerzők fókusza, és nagy hiányát érzem egy, a párhuzamos kérdőívezések tapasztalatait összevető szintetizáló fejezetnek. A kötet rámutatott arra, hogy bizonyos területi sajátosságok (pl. periferikusság, településszerkezet) egymástól térben távol eső, eltérő társadalmi-gazdasági helyzetü régiókban is felvetnek hasonló kihívásokat, ám erre az eltérő társadalmi, gazdasági környezetben már eltérő megoldási kísérletek születhetnek, és emiatt a lakosság saját helyzetének megítélése, helyi szociális ellátórendszerekkel kapcsolatos percepciója is eltérően alakulhat. Épp ezért a kötet hiányosságai ellenére nyugodt szívvel ajánlható a téma iránt érdeklődő kutatóknak.

\section{Irodalom}

Juhász A., Nagy Cs., Páldy A., Beale, L. (2010): Development of deprivation index and its relation to premature mortality due to diseases of the circulatory system in Hungary, 1998-2004. Social Science \& Medicine, 9., 1342-1349. http://doi.org/cwbq6n 